International Journal of Health Sciences
Available online at www.sciencescholar.us
Vol. 6 No. 1, April 2022, pages: $366-377$
e-ISSN: 2550-696X, p-ISSN: 2550-6978
https://doi.org/10.53730/ijhs.v6n1.4488

\title{
Method of Forming Professional Competencies Future Teacher for Labor Education
}

\author{
CrossMark \\ Oleksandr Bordiuk a, Yurii Shpylovyi ${ }^{\text {b }}$, Liudmyla Tkachenko ${ }^{c}$, Oleh Khyshchenko d, $^{d}$ \\ Alyona Yushchenko ${ }^{e}$, Tetiana Slaboshevska ${ }^{f}$
}

Manuscript submitted: 27 September 2021, Manuscript revised: 7 December 2021, Accepted for publication: 22 January 2022

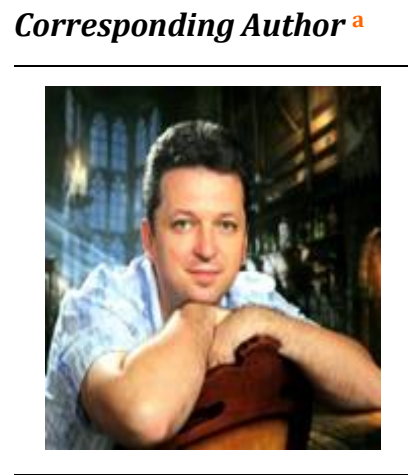

Keywords

distance education; educational process; educational source; media education; media pedagogy; modern education; pandemic condition; pedagogical education;

\begin{abstract}
The purpose of the article is to theoretical studying scientific developments and systematization of practical data on the features of acquiring skills in computer competence by digital technology specialists under the conditions of the pandemic. Societal challenges related to the digital transformation of the economy, production, management, and social relations undoubtedly affect the education system, primarily by changing approaches to the learning process. While in the conditions of evolutionary transformation this happens gradually, then in crises they cause unpredictably fast, and, accordingly, require quick and high-quality decisions. Using different learning methods during the pandemic has raised the issue of the quality of the educational process not only in Ukraine but also around the world. Materials and Methods. A range of bibliosemantic and analytical methods have been used in the research to study the issues outlined.
\end{abstract}

\section{Contents}

Abstract

1 Introduction.

2 Materials and Methods

\footnotetext{
a National Pedagogical Dragomanov University, Kiev, Ukraine

b National Pedagogical Dragomanov University, Kiev, Ukraine

c National Pedagogical Dragomanov University, Kiev, Ukraine

d Hryhorii Skovoroda University in Pereiaslav, Pereiaslav, Ukraine

e National Pedagogical Dragomanov University, Kiev, Ukraine

f National Pedagogical Dragomanov University, Kiev, Ukraine
} 


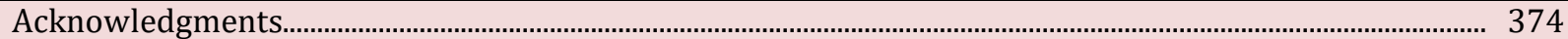

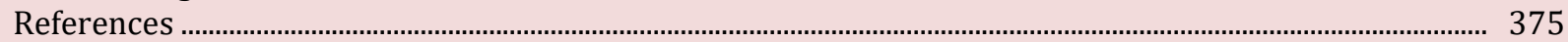

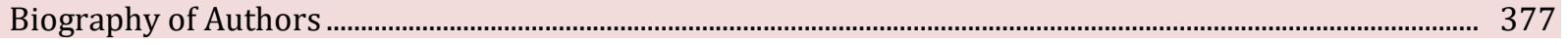

\section{Introduction}

The most important feature of the modern world system is globalization, which is a multi-vector process taking place simultaneously at different levels, namely: market, financial, and production, as well as at the level of communication. Globalization in the field of communication is an unimpeded movement of information flows, in which media content circulates regardless of the actual location of its creators. In this regard, it is expedient to study media understanding (Spirin \& Ostrjans'ka, 2021; Mears-Delgado \& Marzal, 2018).

The leading activity of the students is self-education. The quality of the educational process is directly related to skills to acquire new knowledge and apply it in real life. Against this background, the necessity for prepared information competence of the personality has significantly increased (DuBenske et al., 2010; Pinto et al., 2013). Information literacy includes the formation of skills as follows: the ability to work independently with information, search, select, analyze and evaluate, organize, present, transmit it; model, design objects and processes, including in the framework of interaction with other participants in the educational process, implement their plans responsibly, make decisions and act in unforeseen situations, learn throughout life. The development of this competence among students is considered one of the most significant prerequisites for their professional development (Spirin \& Ostrjans'ka, 2021).

The growing role of informatization brings with it many objectives connected with the necessity to provide society with IT professionals. The study of educational sources and electronic resources has revealed that currently, scientists have conducted a significant number of investigations related to information technologies. Along with this, under the conditions of permanent quarantine, the process of forming information literacy of IT professionals has acquired specific features. Nowadays, the participants of the educational process use the latest distance technologies to improve their professional level. Researchers are considering different areas of IT education; however, some aspects need further investigation (Al-Okaily et al., 2020).

\section{Literature review}

Recently, modern software has been actively introduced in business and education. This is not surprising, forasmuch as the transition of companies and institutions in all industries to the format of working by applying digital tools has numerous advantages, namely: increasing the efficiency of employees, reducing company costs, improving financial management, optimizing the process of planning and monitoring work. Alongside the acceleration of digital business processes around the world and the growing base of online applications for regular users, businesses in all industries will grow because digital applications become more popular, contributing to the additional engagement of customers (Calatayud et al., 2018).

With this in mind, there is a general trend of rapid growth in demand for IT professionals in all areas of human activity, as well as increasing demands on the professionalism of future professionals. Against the background of increasing the number of students in the IT-sphere, the educational environment lags behind the rapidly changing technologies and tools of the IT industry. Issues of training IT specialists are constantly at the center of attention of the modern information society. These reasons significantly increase the urgency of the problem of training highly qualified, competent personnel in the field of information technologies. The study of the specifics of the professional training of IT specialists is of particular relevance under the conditions of the pandemic, exacerbating the problem of choosing effective tools for training digital technology specialists. This is precisely why currently it is sufficiently important to form information literacy of IT workers, ensuring their effective mastering of the principles of working with educational information systems (Malihin \& Jarmol'chuk, 2020). Information competence is the ability to retrieve, understand, process, and use information from different sources (Kogut, 2018). Information skills are one of the core competencies for lifelong study, active citizenship, and employment defined by the European Union.

Bordiuk, O., Shpylovyi, Y., Tkachenko, L., Khyshchenko, O., Yushchenko, A., \& Slaboshevska, T. (2022). Method of forming professional competencies future teacher for labor education. International Journal of Health Sciences, 6(1), 366-377. https://doi.org/10.53730/ijhs.v6n1.4488 
In the 1950s, one of the most famous American sociologists of the XX century, D. Bell, created the theory of post-industrial society, which covers virtually all the fundamentals of the information society, the transition to which took place in the late XX century. In his viewpoint, our society has an informational social structure (Banerjee et al., 2020; Varotsos et al., 2021). Martin V. draws particular attention to the fact that communication skills are a major prerequisite for development in the modern world. One of the most interesting and developed philosophical concepts of the information society has been identified by Kyzym M., who considers computer technology as the basis of a new society. He pays special emphasis to the transformation of human values in the global information society (Kyzym et al., 2020).

Many researchers have studied the success of applying information tools in IT education at educational institutions, developed the basic principles of selection and use of IT tools in modern computer science education. Thus, the role of digital methodology and practice of modern education is considerable. However, currently, there are no studies on the training and development of future IT specialists in the field of business informatics (Rivas et al., 2019; Hepsiba et al., 2018).

Taking into account the rapid pace of development and improvement of informatization of all aspects of the society, it is necessary to pay permanent attention to educational strategies and vectors of their implementation, aimed at improving the effectiveness of training IT professionals. Thus, such scientists, as Strohmeier (2020) and Sales (2020), have considered the possibility of using information technology in the professional activities of future specialists in digital technology.

Kyzym et al. (2020), have investigated and experimentally confirmed the importance of information and communication literacy of employees. By the way, they have studied the requirements of the labor market which should be met by the graduate of modern business educational institutions, taking into consideration the challenges of tendencies in higher education. Sales et al. (2020), have theoretically substantiated and experimentally confirmed the quality of big data in the education of a modern university.

Dawes (2019), has studied the specifics of training IT specialists, taking into account the computerization of society. Cabero-Almenara et al. (2020), have conducted scientific investigations on information technologies in education. Castañeda et al. (2018), have studied, experimentally tested, and theoretically substantiated the use of cloud tools in the education process.

The conditions of distance education have been also investigated by Ghebreyesus, Tedros-Adhanom; Ng, Alex. The results of their studies are outlined in the recommendations for the development and effective use of distance learning courses (Ghebreyesus \& Tedros-Adhanom 2020). As mentioned by Kliuchnyk et al. (2021) and Strikha et al. (2021), regional authorities and municipalities in many countries pay considerable attention to IT education, especially in the context of pandemics and quarantine restrictions.

An important aspect in the education of future IT professionals is the ability to work freely with software products adapted for beginners. This makes it possible to get out of the space of one-dimensional IT education and the transition to a multidimensional IT space, a complete alternative and free choice of one's professional strategy (Jacobson et al., 2020; Nga, 2021).

According to the viewpoint of N. Bobrov, the specifics of such training is the development of critical thinking, constructiveness, associativity, and heuristics, which help to formulate and solve non-standard problems of the modern society based on systematic thinking and understanding the role and place of information processes in the society (Malihin \& Jarmol'chuk, 2020).

\section{Materials and Methods}

A range of bibliosemantic and analytical methods was used in this research to study the issues outlined. To explore the importance of digital competencies and tools for improving it by future and present specialists, in December 2021 was surveyed at Igor Sikorsky Kyiv Polytechnic Institute (Ukraine). The survey was held among employers for IT professionals, students, and academic staff of the University. 


\section{Results and Discussions}

Analyzing the degree of using electronic tools by Ukrainian enterprises in 2017-2019, it has been revealed that the level of digitalization of their activities is quite high (Table 1; Figure 1).

Table 1

Dynamics of the level of using information and communication technologies by Ukrainian enterprises in 2017 $2019, \%$

\begin{tabular}{|c|c|c|c|c|c|}
\hline \multirow[b]{2}{*}{ Indicator } & \multicolumn{3}{|c|}{ Year } & \multicolumn{2}{|c|}{ Deviation } \\
\hline & 2017 & 2018 & 2019 & $\begin{array}{l}2018- \\
2017\end{array}$ & $\begin{array}{l}2019- \\
2018\end{array}$ \\
\hline \multicolumn{6}{|c|}{$\begin{array}{l}\text { Proportion of enterprises that conducted training in the field } \\
\text { of ICT out of the total number of enterprises: }\end{array}$} \\
\hline training courses for professionals, $\%$ & 3,7 & 3,8 & 4,6 & 0,1 & 0,8 \\
\hline training for other employees, $\%$ & 4,1 & 4,3 & 4,8 & 0,2 & 0,5 \\
\hline \multicolumn{6}{|l|}{$\begin{array}{l}\text { Proportion of enterprises that used the Internet for } \\
\text { purposes: }\end{array}$} \\
\hline sending or receiving e-mails, $\%$ & 86,9 & 85,4 & 98,4 & $-1,5$ & 13 \\
\hline Internet conference, $\%$ & 27,8 & 28,5 & 30,4 & 0,7 & 1,9 \\
\hline obtaining information about goods and services, \% & 78,2 & 77,1 & 87,6 & $-1,1$ & 10,5 \\
\hline bulletin board, \% & 43 & 42,7 & 47,3 & $-0,3$ & 4,6 \\
\hline \multicolumn{6}{|l|}{ use of instant messaging and electronic receipt of } \\
\hline $\begin{array}{l}\text { miormation irom pubic authorities, } \% \\
\text { contacts with government agencies, } \%\end{array}$ & $\begin{array}{l}7,2 \\
45,6\end{array}$ & 46,1 & 50,9 & $\begin{array}{l}-0,0 \\
0,5\end{array}$ & 4,8 \\
\hline conducting banking transactions, $\%$ & 85,5 & 84,3 & 96,6 & $-1,2$ & 12,3 \\
\hline access to other financial services, $\%$ & 35,8 & 35,8 & 39,2 & 0 & 3,4 \\
\hline
\end{tabular}

Source: Reshetnjak \& Bilousov, 2021

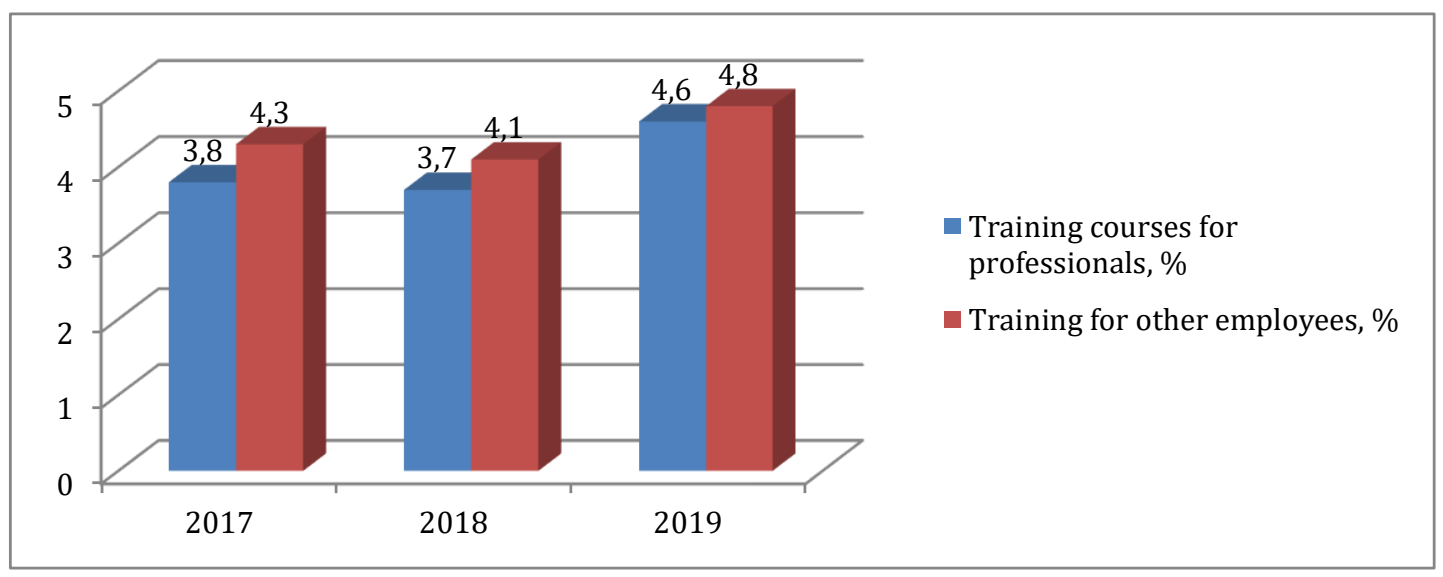

Figure 1. The proportion of enterprises that conducted training in the field of ICT out of the total number of enterprises

Source: according to Reshetnjak \& Bilousov (2021)

As it can be observed from Table 1, the Internet was used by domestic companies mainly for sending or receiving e-mails $(2017-86,9 \%, 2019-98,4 \%)$, for banking transactions $(2017-85,5 \%, 2019-96,6)$, used for receiving information about goods and services $(2017-79,8 \%, 2019-70,4 \%)$. Thus, the above data have

Bordiuk, O., Shpylovyi, Y., Tkachenko, L., Khyshchenko, O., Yushchenko, A., \& Slaboshevska, T. (2022). Method of forming professional competencies future teacher for labor education. International Journal of Health Sciences, 6(1), 366-377. https://doi.org/10.53730/ijhs.v6n1.4488 
proven that the activity of transforming business processes of enterprises into digital format is significant, and, therefore, we can estimate the need for qualified IT professionals as large and increasing.

To research the importance of general areas of digital competence and tools for improving it by students and graduates, in December 2021, a survey of employers of IT professionals, students, graduates, and teachers of higher educational institutions has been conducted, which trains specialists in this field (Igor Sikorsky Kyiv Polytechnic Institute). The results of the survey are given below (Figure 2, 3, 4, 5).

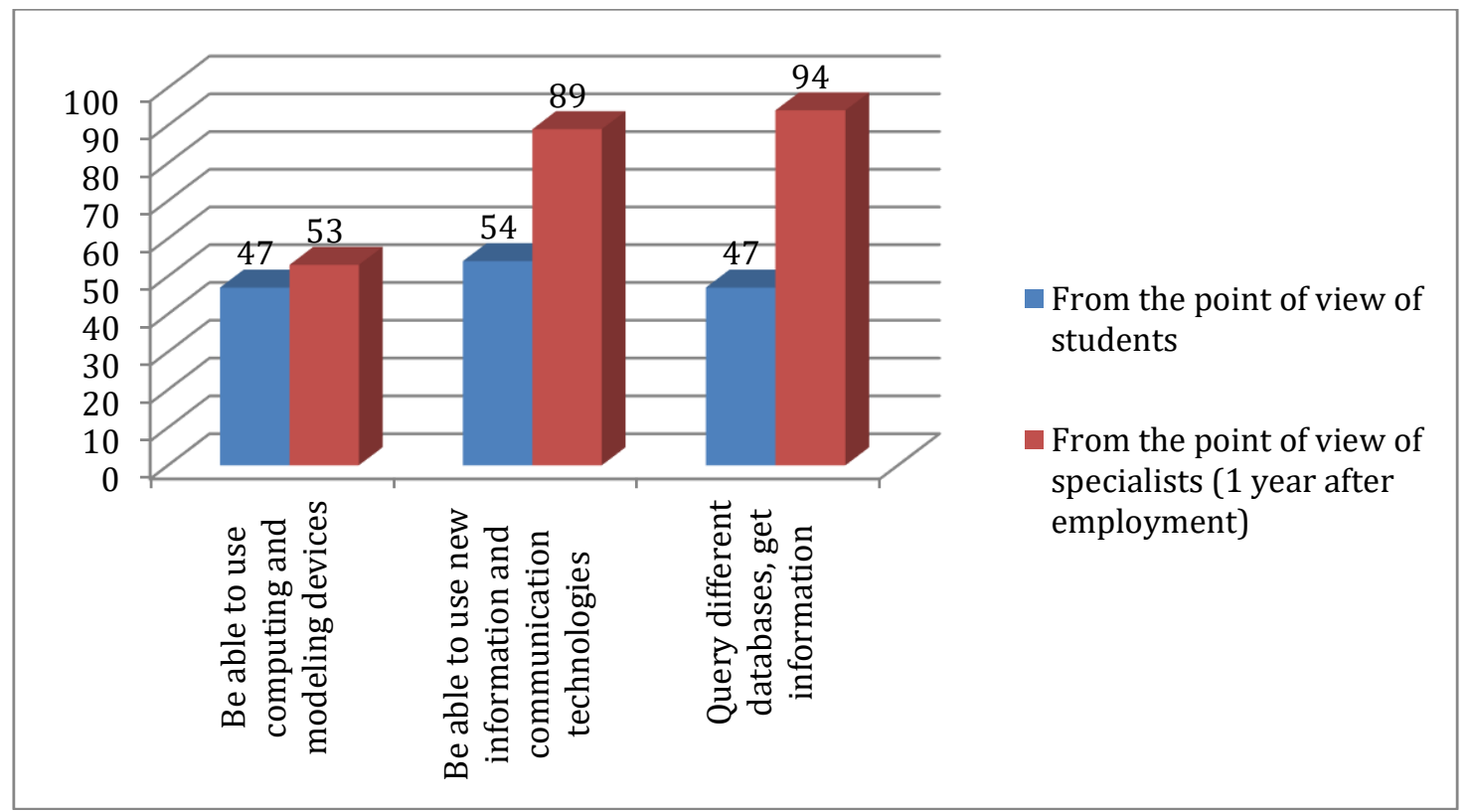

Figure 2. The importance of different types of information skills for educational/professional activities Source: Compiled by the authors

As we can see, for students and specialists who have already started working in IT specialties, the main important skills for learning and working are the ability to use new information and communication technologies and query different databases, obtain information. Herewith, employees of companies assess the necessity of these skills for their activities higher than students. 


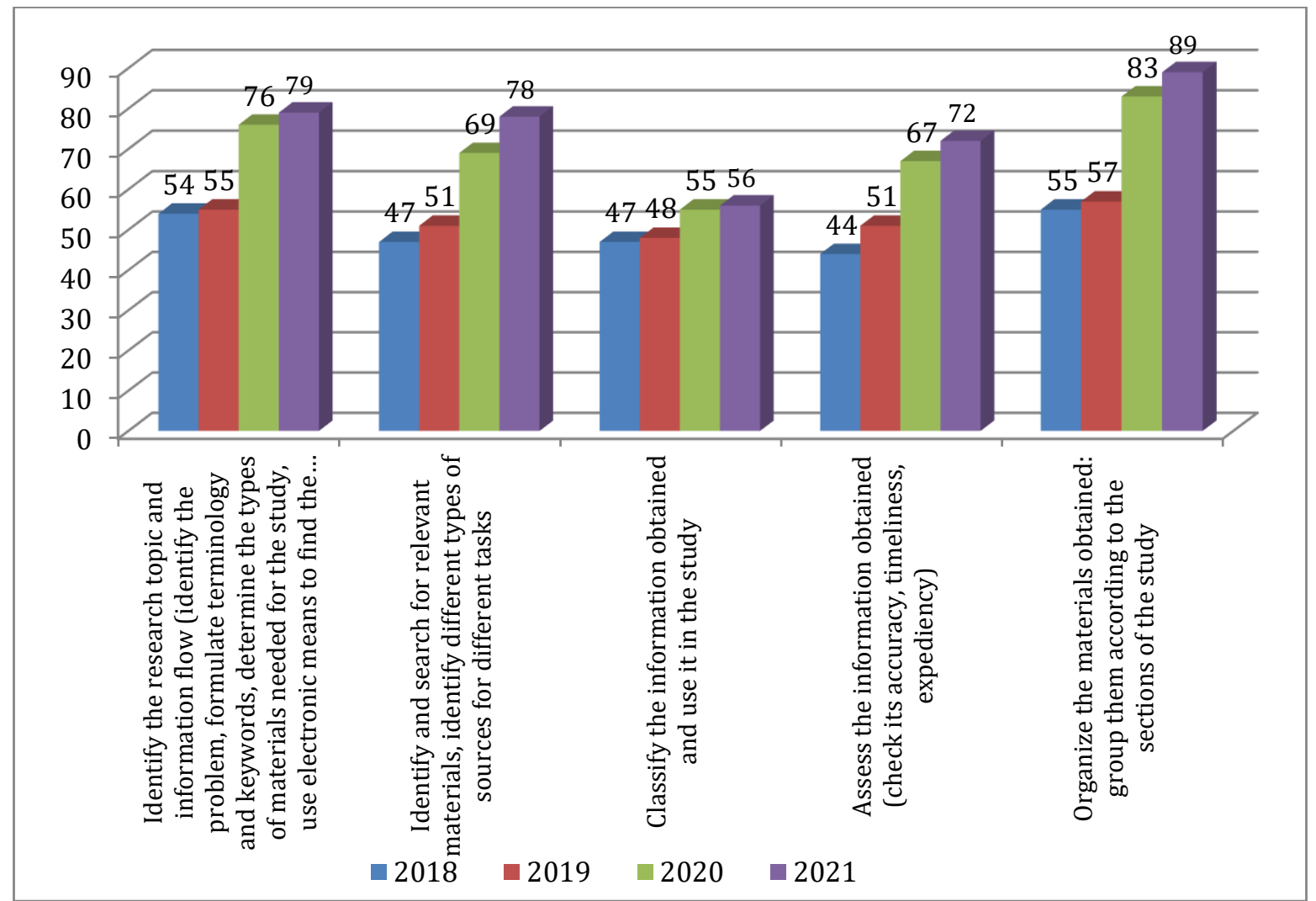

Figure 3. The relevance of certain skills in digital competence according to company executives Source: Compiled by the authors

As we see, the most significant skills in digital competence according to company executives are as follows: the ability of the specialist to identify the problem, formulate terminology and keywords, determine the types of materials needed for research, use electronic means to search for the necessary information, and organize the materials revealed (that is, group them according to the sections of the study). By the way, particular attention is drawn to the positive dynamics of the assessment of importance for almost all skills indicated in the survey.

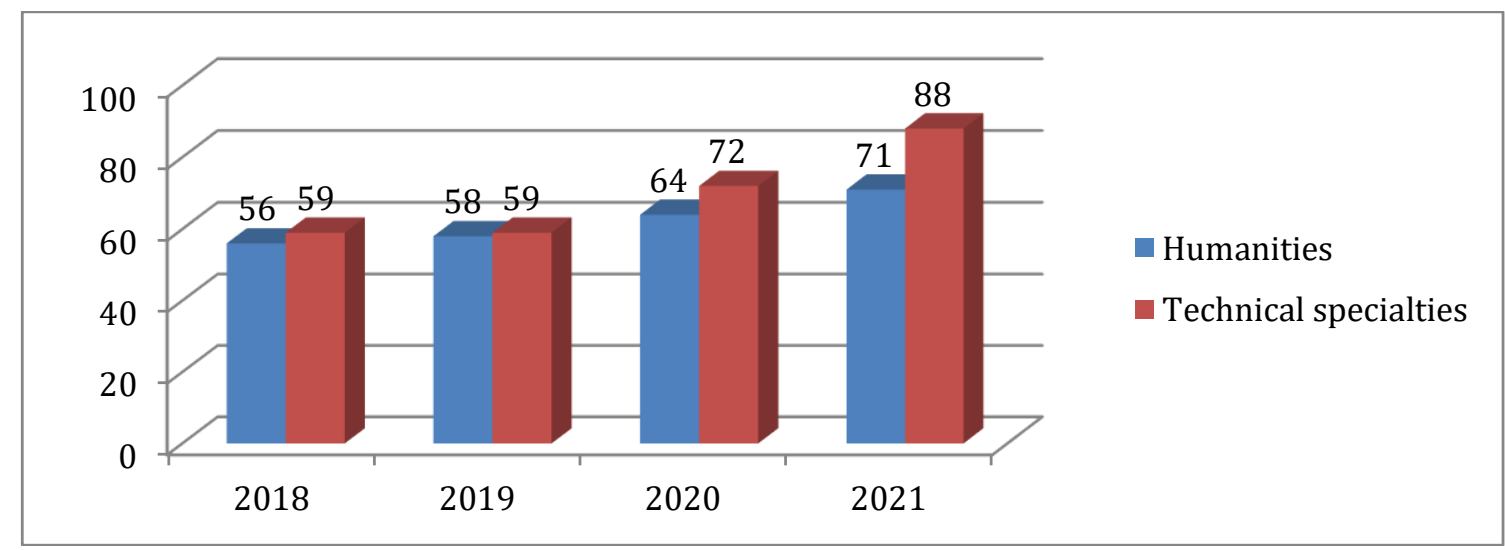

Figure 4. Dynamics of the general level of digital competence of graduates of humanities and technical specialties

Source: Compiled by the authors

Bordiuk, O., Shpylovyi, Y., Tkachenko, L., Khyshchenko, O., Yushchenko, A., \& Slaboshevska, T. (2022). Method of forming professional competencies future teacher for labor education. International Journal of Health Sciences, 6(1), 366-377. https://doi.org/10.53730/ijhs.v6n1.4488 
In general, a gradual increase in the level of digital competence of graduates is observed.

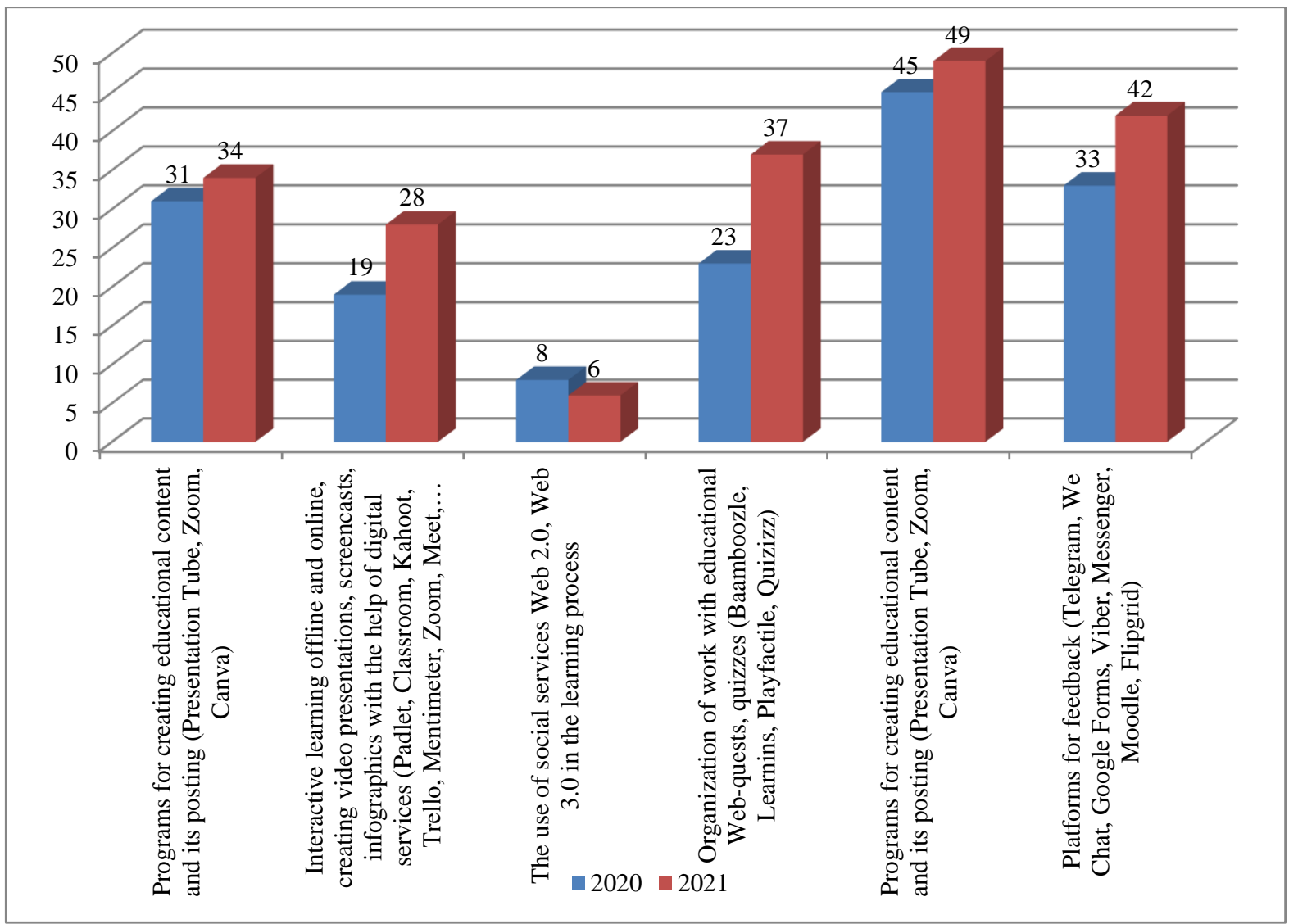

Figure 5. Tools used by IT professionals for improving their skills in the conditions of the pandemic Source: (Sobchenko, 2021)

Therefore, we singled out the most popular programs comprising educational content and information placement among IT professionals are as follows.

\section{Discussion}

Thus, in the process of studying the scientific works of scholars and conducting a survey about information skills of digital technology specialists', were obtained information regarding the components of this concept and tools for its development. According to the viewpoint of Galaevs'ka (2021), information and communication literacy of the individual is a person's ability, on the one hand, to navigate in a dynamic socialcultural environment and space of different cultures, and on the other hand - to expand information and knowledge, develop one's communication style, personal activity, new principles of interaction transformations.

Along with this, Reshetnyak \& Bilousov (2021), define ICT competence as the ability of a person to address educational, life, and professional issues by using information and communication technologies. According to the viewpoint of Manso-Perea et al., (2019), information literacy is defined as the ability to effectively conduct information activities (in solving professional problems, learning, everyday life) by applying ICT, implying the possession of information literacy at the required level (including personal characteristics), to solve relevant tasks based on experience, the ability to independently organize one's activities, to conduct self-control of one's actions with an awareness of the personal role and possible consequences of their implementation.

The rapid development and spread of digital technologies, the growth of information, and the expansion of its consumption not only open new opportunities but also pose new challenges to modern society, including the 
education system (Papadopoulos et al., 2020; Elia et al., 2020). They are reflected in the requirements that modernity puts forward to the individual and the development of his cognitive abilities, the need to overcome the deep contradictions between the pace of social and individual social-cultural development. Scientific investigators note the accelerated development of media and educational structures. The preparation of the younger generation for life in a mediated society in the mode of constant dialogue with the media and communication is recognized as an urgent issue. Accordingly, the basic personal skills, which are specifically formed by the subjects of training and education nowadays, include as follows: knowledge, skills, abilities, and experience in their application (Naslund et al., 2017; Ginaya et al., 2020).

Effective addressing a problem of preparing the new generation for life under modern information conditions is carried out by domestic and foreign teachers with the introduction of media pedagogical education models. The major directions of educational activities are as follows: the use of mass communication and media pedagogy for the development of orientation skills in the information sphere, resistance to manipulation by consciousness, and for positive self-development (moral, aesthetic, socialcultural, legal, etc.). An important point in this process is the search for new paradigms and styles of thinking, the desire to abandon the one-sided approach to social development, and the informatization of society (Vie, 2021; Chen et al., 2018).

The information society opens unprecedented opportunities for access to information and knowledge, allows everyone to fulfill one's potential, and improves life quality. At the same time, the information society is fraught with many risks and challenges. In conditions of a vast amount of information, it is becoming increasingly difficult to navigate, receive and process the necessary information. The speed of the spread of modern information technologies creates the danger of manipulating the consciousness and behavior of a person, threatening dehumanization.

Media education, as a sphere of acquiring skills of social-pedagogical direction, is aimed at adapting people to social-cultural changes based on new technological achievements. According to the viewpoint of the British scientist and media pedagogue L. Masterman, media education is relevant and in demand in the modern world for seven reasons, namely:

- The growth of national and international information processes is rapid;

- A constant emergence of a large amount of media information is taking place, strengthening the mechanisms for its distribution and management;

- The importance of visual communication and information in all areas is increasing;

- A high media consumption and saturation of modern societies with mass media is observed;

- The intensity of media penetration of the most important democratic processes is significant;

- The ideological significance of the media and its influence on public consciousness;

- The need to educate students/graduates with an emphasis on future compliance.

The globalization of the media with the help of the scientific and technological revolution has changed people's perception of the world. The information space is expanding, which inevitably leads to changes in the concept of culture. The material of the research shows that under the conditions of globalization influence, new concepts arise and the existing ones are transformed at the level of conceptual, figurative, and valueoriented components of concepts, which is explained by the desire of the society not only to understand but also to develop new phenomena, stimulating a certain attitude towards them. In the era of information development of civilization, a person should acquire competencies of different levels, as well as possess new qualities (Diachenko et al., 2021; Widana et al., 2021).

An information culture of IT specialists has become relevant for society. In recent years, the focus has shifted to the field of search analysis, popular professional methods that help to collect, evaluate information, etc. are in demand. Media education forms a mentality, developing the necessary abilities to perceive and evaluate events in the modern world, the ability to communicate with the media. Lazarenko et al. (2021), recommend the following areas of optimizing the introduction of digital technologies in the educational process:

Bordiuk, O., Shpylovyi, Y., Tkachenko, L., Khyshchenko, O., Yushchenko, A., \& Slaboshevska, T. (2022). Method of forming professional competencies future teacher for labor education. International Journal of Health Sciences, 6(1), 366-377. https://doi.org/10.53730/ijhs.v6n1.4488 
- To promote a broader discussion with all stakeholders on the introduction of digital technologies, accessibility, and efficiency of education and preparing future professionals for life in the information society;

- Inclusion of provisions relating to digital literacy in regulations (digital competence), recognized by the European Union as one of the keys to the fulfillment of life potential;

- Stimulating the development of digital educational space, creating open databases and Internet resources on the activities of educational institutions, educational authorities, which will ensure the transparency of decision-making and ensure public control over the use of ICT in education;

- Assistance in the development the digital education taking into account the current directions of its development (distance and blended learning);

- Virtual modeling and infographics of the essence of phenomena and objects of the surrounding world; digital measurement, digitization of properties of real and educational objects;

Supporting and promoting the initiatives of public and private educational institutions on the use of modern educational information technologies (Lazarenko et al., 2021).

\section{Conclusion}

Thus, the analysis of the scientific literature has shown that the competence of IT professionals not only allows them to master the languages and codes of the modern information field but also develop personal skills, forming a certain type of social and ideological thinking. The research conducted has made it possible to outline the directions of the priority components of IT specialists' information competence, which are necessary for their further professional activities and, as the survey has revealed, are highly sought in all branches of human activity.

Acknowledgments

We are grateful to two anonymous reviewers for their valuable comments on the earlier version of this paper 


\section{References}

Al-Okaily, M., Alqudah, H., Matar, A., Lutfi, A., \& Taamneh, A. (2020). Dataset on the Acceptance of e-learning System among Universities Students' under the COVID-19 Pandemic Conditions. Data in brief, 32, 106176. https://doi.org/10.1016/j.dib.2020.106176

Banerjee, A., Pasea, L., Harris, S., Gonzalez-Izquierdo, A., Torralbo, A., Shallcross, L., ... \& Hemingway, H. (2020). Estimating excess 1-year mortality associated with the COVID-19 pandemic according to underlying conditions and age: a population-based cohort study. The Lancet,395(10238), 1715-1725. https://doi.org/10.1016/S0140-6736(20)30854-0

Cabero-Almenara, J., Barroso-Osuna, J., Rodríguez, A. P., \& Llorente-Cejudo, C. (2020). Marcos de Competencias Digitales para docentes universitarios: su evaluación a través del coeficiente competencia experta. Revista electrónica interuniversitaria de formación del profesorado, 23(3).

Calatayud, V. G., García, M. R., \& Espinosa, M. P. P. (2018). Formación en competencias digitales para estudiantes universitarios basada en el modelo DigComp. Edutec. Revista electrónica de tecnología educativa, (65), 1-15.

Castaneda, L., Esteve, F., \& Adell, J. (2018). Why rethinking teaching competence for the digital world?. RedRevista De Educacion A Distancia, (56).

Chen, D. T., Lin, T. B., Li, J. Y., \& Lee, L. (2018). Establishing the norm of new media literacy of Singaporean students: Implications to policy and pedagogy. Computers \& Education, 124, 1-13. https://doi.org/10.1016/j.compedu.2018.04.010

Dawes, L. (2019). Through faculty's eyes: Teaching threshold concepts and the framework. Portal: Libraries and the academy, 19(1), 127-153.

Diachenko, A., Vusyk, H., Bielova, Y., Shurdenko, M., \& Titenko, O. (2021). The educational role in COVID-19 terms of ethnodesign graphic function in higher education practical activities. International Journal of Health Sciences, 5(3), 584-593. https://doi.org/10.53730/ijhs.v5n3.2540

DuBenske, L. L., Chih, M. Y., Gustafson, D. H., Dinauer, S., \& Cleary, J. F. (2010). Caregivers' participation in the oncology clinic visit mediates the relationship between their information competence and their need fulfillment and clinic visit satisfaction. Patient education and counseling, 81, S94-S99. https://doi.org/10.1016/j.pec.2010.08.022

Elia, G., Margherita, A., \& Passiante, G. (2020). Digital entrepreneurship ecosystem: How digital technologies and collective intelligence are reshaping the entrepreneurial process. Technological Forecasting and Social Change, 150, 119791. https://doi.org/10.1016/j.techfore.2019.119791

Gala€vs'ka, L. (2021). Formation of information competence of high school students in Ukrainian language lessons. Naukovij visnik Uzhgorods'kogo universitetu. 1(48).

Ghebreyesus \& Tedros-Adhanom; Ng, Alex (2020). Desinformación frente a medicina: hagamos frente a la 'infodemia'. El país, 18 febrero.

Ginaya, G., Kanca, I. N., \& Sri Astuti, N. N. (2020). Designing problem-based learning (PBL) model for tourism vocational education in 4.0 industry. International Journal of Linguistics, Literature and Culture, 6(1), 14-23.

Hepsiba, N., Subhashini, A., Raju, M., \& Rao, Y. P. (2018). Changing role of teachers in the present society. International Journal of Health \& Medical Sciences, 1(1), 35-38.

Jacobson, T., Mackey, T., O’Brien, K., Keiffert, J.(act.), Sales, D. (trad.) (2020). Metas y objetivos de aprendizaje de la meta-alfabetización.

Kliuchnyk, A., Shebanin, V., Shebanina, O., Kormyshkin, Y., Rybachuk, V., \& Buryk, Z. (2021). Strategic Factors Quality Of Public Administration In Regional Development: The Experience Of Eu Countries. International Journal for Quality Research, 15(4), 1317.

Kogut, I. (2018) Information competence as a structural component of professional and pedagogical communicative competence of a teacher in the modern educational space. Osvitologichnij diskurs, 3-4 (2223).

Kyzym, M., Khaustova, V., Reshetnyak, O., Timohova, G., \& Sakhnenko, O. (2019). Research Study of the Problems of Human Resourcing of the Scientific and Innovation Entrepreneurship. International Journal of Recent Technology and Engineering (IJRTE), 8(3C), 213-218.

Kyzym, M., Reshetnyak, O., \& Bielousov, D. (2020). Forecasting scientific support for the advancement of the digital economy. Estudios de Economía Aplicada, 38(4).

Bordiuk, O., Shpylovyi, Y., Tkachenko, L., Khyshchenko, O., Yushchenko, A., \& Slaboshevska, T. (2022). Method of forming professional competencies future teacher for labor education. International Journal of Health Sciences, 6(1), 366-377. https://doi.org/10.53730/ijhs.v6n1.4488 
Lazarenko, N., Gurevich, R. \& Kizim, S. (2021). Transformational processes in education: methodology, theory, experience, problems. Visnik Nacional'noï akademiï pedagogichnih nauk Ukraïni, 3(1).

Malihin, 0. \& Jarmol'chuk, T. (2020). Current learning strategies in the training of information technology professionals. Informacijni tehnologiï i zasobi navchannja. 76(2).

Manso-Perea, C., Cuevas-Cerveró, A., González-Cervantes, S. (2019). Competencias informacionales en los estudios de grado en enfermería: el caso español. Revista española de documentación científica, 42(1).

Mears-Delgado, B., \& Marzal, M. A. (2018). Evalfin: A model for the evaluation of information literacy in higher education institutions.

Naslund, J. A., Aschbrenner, K. A., Araya, R., Marsch, L. A., Unützer, J., Patel, V., \& Bartels, S. J. (2017). Digital technology for treating and preventing mental disorders in low-income and middle-income countries: a narrative review of the literature. The Lancet Psychiatry, 4(6), 486-500. https://doi.org/10.1016/S22150366(17)30096-2

Nga, M. P. T. Q. (2021). Educational points the control of wrong points and environments on social networks for students. International Journal of Linguistics, Literature and Culture, 8(1), 13-18.

Papadopoulos, T., Baltas, K. N., \& Balta, M. E. (2020). The use of digital technologies by small and medium enterprises during COVID-19: Implications for theory and practice. International Journal of Information Management, 55, 102192. https://doi.org/10.1016/j.ijinfomgt.2020.102192

Pinto, M., Fernández-Ramos, A., Sánchez, G., \& Meneses, G. (2013). Information competence of doctoral students in information science in Spain and Latin America: A self-assessment. The journal of academic librarianship, 39(2), 144-154. https://doi.org/10.1016/j.acalib.2012.08.006

Reshetnjak, O. \& Bilousov, D. (2021). Features of training in the context of digital competitiveness. Efektivna ekonomika, 1.

Rivas, W. R. S., Martín, S. C., González, M. C., \& Barrientos, A. (2019). La Educomunicación en el contexto de alfabetización de personas jóvenes y adultas en América Latina: estado de la cuestión a partir de una revisión bibliográfica sistemática. Revista latina de comunicación social, (74), 133-171.

Sales, D. (2020). Definición de alfabetización informacional de CILIP, 2018. In Anales de documentación (Vol. 23, No. 1). Facultad de Comunicación y Documentación y Servicio de Publicaciones de la Universidad de Murcia.

Sales, D., Cuevas-Cerveró, A., \& Gómez-Hernández, J. A. (2020). Perspectives on the information and digital competence of Social Sciences students and faculty before and during lockdown due to Covid-19.

Sobchenko, T. (2021) The use of digital tools in postgraduate pedagogical education. Scientific Bulletin of Uzhhorod University Series. Pedagogy Social Work, 1(48).

Spirin, O. \& Ostrjans'ka, O. (2021). Professional development of specialists in the conditions of digitalization of society. Conference on professional development of specialists in the digitized society: current trends: scientific and practical conference with international participation: proceedings (selected papers)/ scientific edition Oleg Spirin, Olena Ostrianska. Zhytomyr: Zhytomyr Ivan Franko State University, 2021.

Strikha, L., Mamontova, E., Vonsovych, S., Voropayeva, T., Buryk, Z., \& Baranova, O. (2021). The modern experience of lobbying interests in Europe. Estudios de Economia Aplicada.

Strohmeier, S. (2020). Digital human resource management: A conceptual clarification. German Journal of Human Resource Management, 34(3), 345-365.

Varotsos, C. A., Krapivin, V. F., \& Xue, Y. (2021). Diagnostic model for the society safety under COVID-19 pandemic conditions. Safety Science, 136, 105164. https://doi.org/10.1016/j.ssci.2021.105164

Vie, S. (2021). The invisible labor of social media pedagogy: A case study of\# TeamRhetoric community$\begin{array}{llll}\text { building on } \quad \text { Twitter. Computers } & 102639 .\end{array}$ https://doi.org/10.1016/j.compcom.2021.102639

Widana, I.K., Sumetri, N.W., Sutapa, I.K., Suryasa, W. (2021). Anthropometric measures for better cardiovascular and musculoskeletal health. Computer Applications in Engineering Education, 29(3), 550561. https://doi.org/10.1002/cae.22202 


\section{Biography of Authors}

\begin{tabular}{|c|c|}
\hline & $\begin{array}{l}\text { Oleksandr Bordiuk } \\
\text { Candidate of Pedagogical Sciences, Associate professor, Department of } \\
\text { Information Systems and Technology, National Pedagogical Dragomanov } \\
\text { University, Kyiv, Ukraine. } \\
\text { ORCID: 0000-0003-0729-2571 } \\
\text { Email: o.m.bordyuk@npu.edu.ua }\end{array}$ \\
\hline & $\begin{array}{l}\text { Yurii Shpylovyi } \\
\text { Candidate of Pedagogical Sciences, Associate professor, Department of } \\
\text { Information Systems and Technology, National Pedagogical Dragomanov } \\
\text { University, Kyiv, Ukraine. } \\
\text { ORCID: 0000-0001-6365-2661 } \\
\text { Email:yu.v.shpylovyy@npu.edu.ua }\end{array}$ \\
\hline & $\begin{array}{l}\text { Liudmyla Tkachenko } \\
\text { Candidate of Pedagogical Sciences, Associate professor, Department of } \\
\text { Information Systems and Technology, National Pedagogical Dragomanov } \\
\text { University, Kyiv, Ukraine. } \\
\text { ORCID:0000-0003-3491-5535 } \\
\text { Email: l.a.kulish@npu.edu.ua }\end{array}$ \\
\hline & $\begin{array}{l}\text { Oleh Khyshchenko } \\
\text { Candidate of Pedagogical Sciences, Associate Professor, Department of Theory of } \\
\text { Methods of Technological Education and Computer Graphics, Hryhorii Skovoroda } \\
\text { University in Pereiaslav, Ukraine. } \\
\text { ORCID:0000-0002-2653-9421 } \\
\text { Email: lezik30@gmail.com }\end{array}$ \\
\hline & $\begin{array}{l}\text { Alyona Yushchenko } \\
\text { Candidate of Pedagogical Sciences, Associate professor, Department of } \\
\text { Information Systems and Technology, National Pedagogical Dragomanov } \\
\text { University, Kyiv, Ukraine. } \\
\text { ORCID: 0000-0002-0143-3663 } \\
\text { Email:a.p.mykytenko@npu.edu.ua }\end{array}$ \\
\hline & $\begin{array}{l}\text { Tetiana Slaboshevska } \\
\text { Candidate of pedagogical sciences, associate professor, Department of Information } \\
\text { Systems and Technology, National Pedagogical Dragomanov University, Kyiv, } \\
\text { Ukraine. } \\
\text { ORCID: 0000-0002-8468-4950 } \\
\text { Email: t.m.slaboshevska@nрu.edu.ua }\end{array}$ \\
\hline
\end{tabular}

Bordiuk, O., Shpylovyi, Y., Tkachenko, L., Khyshchenko, O., Yushchenko, A., \& Slaboshevska, T. (2022). Method of forming professional competencies future teacher for labor education. International Journal of Health Sciences, 6(1), 366-377. https://doi.org/10.53730/ijhs.v6n1.4488 